\title{
DELAYS IN INITIAL REFERRAL, DIAGNOSIS AND TREATMENT IN CHILDREN WITH CANCER
}

\author{
KANSERLI ÇOCUKLARDA ILK YÖNLENDIRME, TANI VE TEDAVIDE GECIKMELER
}

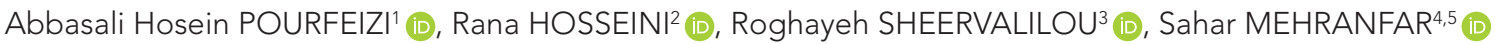 \\ ${ }^{1}$ Tabriz University of Medical Science, Hematology and Oncology Research Center, Tabriz, Iran \\ ${ }^{2}$ Urmia University of Medical Sciences, Social Determinants of Health Research Center, Urmia, Iran \\ ${ }^{3}$ Zahedan University of Medical Science, Zahedan, Iran \\ ${ }^{4}$ Urmia University of Medical Sciences, Faculty of Medicine, Department of Genetics and Immunology, Urmia, Iran \\ ${ }^{5}$ Urmia University of Medical Sciences, Cellular and Molecular Research Center, Urmia, Iran
}

ORCID IDs of the authors: A.H.P. 0000-0003-1251-4730; R.H. 0000-0002-8745-8000; R.S. 0000-0001-7996-845x; S.M. 0000-0001-7831-7102

Cite this article as: Pourfeizi AH, Hosseini R, Sheervalilou S, Mehranfar S. Delays in initial referral, diagnosis and treatment in children with cancer. J Ist Faculty Med 2020;83(3):259-66. doi: 10.26650/IUITFD.2019.0004

\section{ABSTRACT}

Objective: Cancer has been one of the most critical health problems during the past decades which requires serious consideration, especially in developing countries.

Methods: 80 parents of children with different types of cancers were studied via both questionnaire and person-to-person interviews after declaring their informed consent.

Results: The highest delay in patients' initial referral was due to the following factors: lack of attention or ignoring the first symptoms, delay in referring to the physician, low economic status and even lack of family support for the patient. In addition, visiting several doctors after the initial diagnosis, uncertainty about the first proposed method, and the high cost of treatment can be mentioned as the main causes of delays in the start of treatment.

Conclusion: Education plays an important role in identifying the signs of cancer. In addition, proper relationship and cooperation between the health system and physicians as well as provision of adequate information to patients could lead to the long-term cooperation of these patients in continuing their treatment.

Keywords: Cancer, delay in referral, children, delay in diagnosis, delay in treatment

\section{ÖZET}

Amaç: Kanser, son yıllarda, özellikle gelişmekte olan ülkelerde, ciddi dikkat gerektiren en kritik sağlık sorunlarından biri olmuştur.

Yöntem: Farklı kanser türlerine sahip çocukların 80 ebeveyni aydınlatılmış onamları alındıktan sonra hem anket hem de bire bir görüşme yoluyla incelenmiştir.

Bulgular: Hastaların ilk sevkindeki gecikmeler, aşağıdaki faktörlerden kaynaklanmaktadır: dikkat eksikliği veya ilk semptomları görmezden gelme, doktora başvurmada gecikme, düşük ekonomik durum ve hatta hasta için aile desteği eksikliği. Ek olarak, ilk tanıdan sonra farklı doktorlara başvurmak, önerilen ilk yöntem hakkında belirsizlik ve yüksek tedavi maliyeti, tedavinin başlangıcındaki gecikmelerin ana nedenleri olarak gösterilebilir.

Sonuç: Eğitim, kanser belirtilerini anlamada önemli bir rol oynamaktadır. Buna ek olarak, sağlık sistemi ve doktorlar arasında ilişki ve işbirliği ile hastalara yeterli bilgi sağlanması, bu hastaların tedavilerini sürdürmede önemli faktörler olarak görünmektedir.

Anahtar Kelimeler: Kanser, sevkte gecikme, çocuk, tanıda gecikme, tedavide gecikme

Corresponding author/iletişim kurulacak yazar: dr_sahar21@yahoo.com

Submitted/Başvuru: 14.01.2019 • Revision Requested/Revizyon Talebi: 20.03.2019•

Last Revision Received/Son Revizyon: 06.04.2019 • Accepted/Kabul: 06.11.2019 • Published Online/Online Yayın: 24.06.2020

(CTelif Hakkı $2020 \mathrm{~J}$ Ist Faculty Med - Makale metnine jmed.istanbul.edu.tr web sayfasından ulaşılabilir.

(C) Copyright 2020 by J Ist Faculty Med - Available online at jmed.istanbul.edu.tr 


\section{INTRODUCTION}

Since the diagnosis and treatment of this disease in its early stages can reduce the related mortality rates and complications, and tangibly reduce the costs, this study attempts to investigate the factors affecting the patients' initial delay in referring to physicians and then proposes some solutions to tackle this problem and reduce its resultant impact.

Cancer can be defined as the "uncontrollable growth of cells" and it is recognized as a major problem in human societies. It causes the highest mortality rate after heart disease (1). It was Hippocrates (460-370 BC), the Greek physician who used the term "carsino" for the first time to refer to this disease. Later, Celsus (50-28 BC) changed it to "cancer", which means "Scorpion" in the Latin and since then the term cancer has been used to date (2).

Initially, cancer was identified as a problem for the health systems of developed countries; however, in the last decades; 1975 to 2012, its rate has been also increasing in developing countries.

Cancer prevalence rates have increased in all age ranges by $0.6 \%$ per year. In contrast, death rates have dropped constantly, from 6.5 in 1970 to 2.4 in 2012, per 100,000 population (1). For example, the percentage of patients with breast cancer increased from $75 \%$ in 1977 to $90 \%$ in 2009 (3).

The high rates of mortality, economic and psychological consequences as well as the disabilities created by cancer impose a huge cost on the health system of every society. This has motivated the conducting of a plethora of studies for the rapid diagnosis of cancer in its early stages for effective treatment $(4,5)$. With advances in screening, the diagnosis of cancers in their early stages has been made possible. Therefore, many patients can enjoy a good quality of life today because this disease can be diagnosed and treated in early stages (6).

The delay in diagnosis mainly hinges upon two different components:

1. Inattention to the illness symptoms and the patient's delay in referring to a physician (the factors related to the patient).

2. The physician's delay in the initial definitive diagnosis of the disease, which includes the inattention of some physicians to the initial and non-specific symptoms related to cancer, and it is sometimes due to the deceptive and inertial nature of some types of cancers in the early stages (the factors related to the health care system) $(7,8)$. Delay in the diagnosis of cancer leads to an unrealistic incidence in the rate of cancer.
We know that strategic health plans are based on this information and will be influenced by them. These causes lead to the delay in the initiation of early effective treatment, the increased relapse of the disease, no response to treatment and long-term increase of mortality. The present study tried to distinguish the causes of delay in initial referral, diagnosis and onset of treatment. In this way, we can identify the local factors and take a step forward regarding the achievement of the goals set by the World Health Organization in 2014, which emphasizes the early diagnosis with the start of education and training in schools and the implementation of an early perfect treatment plan (8). Particularly, this issue bears high importance in Iran which is currently dealing with a rise in cancer incidents.

\section{METHODS}

In the present study, the participants were selected within one year, from 2015 to 2016, through person-to-person interviews with parents of the patients in the children age group. A total of 93 patients were examined consecutively. The children were divided into two groups, i.e. patients above 7 years of age and 7 years old and below. From all patients, 58 were male and 22 were female with a mean age of $5.93 \pm 3.25$ years old. Graphical abstract is shown in (Figure 1).

The criterion for the inclusion of participants into the study was cancer development for children who had referred to or had been asked to refer to the Children's Hospital of Tabriz for the first time for the diagnosis of cancer or the beginning of treatment.

The patients who were not willing to be interviewed or the ones who had gone through some part of the diagnosis and treatment process in another country were eliminated from participation in this study. The data were collected through questionnaires, which were completed through interviews by the researchers. Those parents who did not provide the researchers with accurate information or opted out of the interview were also excluded from the study.

In this study, each of the delayed referrals, delayed diagnoses, and delayed treatments were identified via the following definitions. Delay in Referring: a delay of more than 30 days from the emergence of symptoms up to the visit to the physician. Delay in diagnosis: a delay of more than 30 days from the first visit to the physician to diagnosis. Delay in treatment: a delay of more than 14 days from diagnosis to treatment.

\section{Statistical analysis}

Normality of data was calculated by Kolmogorov-Smirnov test and expressed by mean and standard deviation in tables. Non-normal variables were implied as median (max \& min). The causes of delays difference between 2 groups; with delay and without delay were assessed by 
independent sample T-test. P-values less than 0.05 were considered statistically significant. All statistical analyses were done using the Statistical package for the Social Sciences (SPSS), version 16.0 (SPSS Inc, Chicago, IL, USA).

\section{Ethical considerations}

The theme of the study was described to all the patients' parents or patients in simple language and the questionnaires with written informed consent were completed with them. The participants were assured that their information would be treated as confidential, would be protected at all research stages, and dissemination of the results would be conducted in an anonymous manner.

\section{RESULTS}

From among 93 patients under study, 13 patients were excluded from the study due to their non-compliance with the inclusion criteria and, thereby, a total of 80 patients were finally evaluated. Table 1 shows the information about the number of patients in each delay group.

\section{Causes of delay in the initial referral}

In total, a delay of more than one month from the first referral was observed in $5 \%$ of the patients. In this study, the relationship of this delay with age, gender, location of residence, occupation, and education of parents was assessed and the following results were obtained:

The relationship between patients' gender and delay in the initial referral

There was no significant correlation $(p>0.05)$ in different groups. Table 2 demonstrates the correlation between gender by each delay.
The relationship between parents' occupation and delay in the initial referral

In this group, similarly, no significant relationship was found; thus, it can be concluded that there was no significant difference between different occupation groups ( $p>0.05)$. Table 3 represents the relevance of parent's occupation and each delay.

The relationship between education level of parents and delay in the initial referral

Parents with elementary education referred to the physician with significantly further delays $(p=0.037)$ in comparison with other educational groups. On the contrary, those with secondary and higher education had the lowest delay. Table 4 shows the relation of parents' education and types of delay groups.

\section{The relationship between children's age and delay in} the initial referral

The patients were divided into two age groups, i.e. patients above 7 years of age, and patients below 7 years of age (based on school age of onset), however there was no significant difference in any of the groups. Table 5 demonstrates the relationship between age range of children and each delay.

The relationship between residence location and delay in the initial referral

Regarding the residence location of patients, there was no significant difference between urban and rural residents in referring to the physician, diagnosis, and treatment of cancer. Table 6 displays the relation between distance of residence and variety of delays.

Table 1. Number of patients in each of delay groups

\begin{tabular}{lccc}
\hline Type of delay & Number of patients & $\mathbf{3 0}$ days & $>\mathbf{3 0}$ days \\
Delayed referral & 80 & 71 & 9 \\
Delayed diagnosis & 80 & 60 & 20 \\
& & $\leq 14$ days & $>14$ days \\
Delayed treatment & 80 & 71 & 9 \\
\hline
\end{tabular}

Table 2. Correlation between gender and delay groups

\begin{tabular}{lccc}
\hline Type of delay & Gender & $\mathbf{3 0}$ days & $>\mathbf{3 0}$ days \\
Delayed referral & Male & 51 & 7 \\
& Female & 20 & 2 \\
Delayed diagnosis & Male & 42 & 16 \\
& Female & 18 & 4 \\
\hline \multirow{2}{*}{ Delayed treatment } & & $\leq 14$ days & $\mathbf{1 4}$ days \\
& Male & 53 & 5 \\
\hline
\end{tabular}


Table 3. Relevance of parent's occupation and length of delay

\begin{tabular}{|c|c|c|c|}
\hline Type of delay & Parent's work & $\leq 30$ days & $>30$ days \\
\hline \multirow[t]{9}{*}{ Delayed referral } & Mother & & \\
\hline & Employee & 5 & - \\
\hline & Farmer & 13 & - \\
\hline & House wife & 60 & 2 \\
\hline & Father & & \\
\hline & Employee & 14 & - \\
\hline & Farmer & 42 & 5 \\
\hline & Businessman & 16 & 1 \\
\hline & Unemployed & 1 & 1 \\
\hline \multirow[t]{10}{*}{ Delayed diagnosis } & Mother & & \\
\hline & Employee & 5 & - \\
\hline & Farmer & 12 & 1 \\
\hline & House wife & 59 & 3 \\
\hline & Father & & \\
\hline & Employee & 12 & 2 \\
\hline & Farmer & 35 & 12 \\
\hline & Businessman & 15 & 2 \\
\hline & Unemployed & 2 & - \\
\hline & & $\leq 14$ days & $>14$ days \\
\hline \multirow[t]{9}{*}{ Delayed treatment } & Mother & & \\
\hline & Employee & 5 & - \\
\hline & Farmer & 12 & 1 \\
\hline & House wife & 59 & 3 \\
\hline & Father & & \\
\hline & Employee & 14 & - \\
\hline & Farmer & 42 & 5 \\
\hline & Businessman & 17 & - \\
\hline & Unemployed & 2 & - \\
\hline
\end{tabular}

Effective factors in delay in the first visit to the physician

About $5 \%$ of the patients had a delay of more than one month before the first visit to the physician.

\section{Causes of delayed diagnosis}

A large number of factors are at play in this regard. Here, the patients' demographic characteristics were evaluated where delayed diagnosis was not significantly correlated with patients' age and gender nor parents' occupation.

\section{Causes of delayed onset of treatment}

Generally, $3.7 \%$ of the children had a delay of more than a month regarding the beginning of treatment.
In this study, the reasons that led to delay in the beginning of treatment include:

\section{Visiting several physicians after the final diagnosis}

From among 18 patients who had a delay of more than 16 days in the beginning of treatment, $77.7 \%$ of them had referred to two or more physicians after the final diagnosis; therefore, these patients had significant delays in regard to the beginning of treatment.

Use of witchcraft, bets and casting of spells as a method of treatment

The parents of $88.8 \%$ of the children had used this method for recovery, but only $7.8 \%$ of the parents mentioned the use of witchcraft as the reason for delay in regard to 
Table 4. Relation parent's education and kinds of delay groups

\begin{tabular}{|c|c|c|c|}
\hline Type of delay & Parent's education & $\leq 30$ days & $>30$ days \\
\hline \multirow[t]{8}{*}{ Delayed referral } & Mother & & \\
\hline & Illiterate & 32 & 7 \\
\hline & Diploma & 18 & 1 \\
\hline & Academic & 21 & 1 \\
\hline & Father & & \\
\hline & Illiterate & 37 & 3 \\
\hline & Diploma & 15 & 4 \\
\hline & Academic & 19 & 2 \\
\hline \multirow[t]{9}{*}{ Delayed diagnosis } & Mother & & \\
\hline & Illiterate & 28 & 11 \\
\hline & Diploma & 14 & 5 \\
\hline & Academic & 18 & 4 \\
\hline & Father & & \\
\hline & Illiterate & 31 & 9 \\
\hline & Diploma & 14 & 5 \\
\hline & Academic & 15 & 6 \\
\hline & & $\leq 14$ days & $>14$ days \\
\hline \multirow[t]{8}{*}{ Delayed treatment } & Mother & & \\
\hline & Illiterate & 37 & 2 \\
\hline & Diploma & 13 & 6 \\
\hline & Academic & 21 & 1 \\
\hline & Father & & \\
\hline & Illiterate & 37 & 3 \\
\hline & Diploma & 14 & 5 \\
\hline & Academic & 20 & 1 \\
\hline
\end{tabular}

Table 5. children age range and length of delay

\begin{tabular}{|c|c|c|c|}
\hline Type of delay & Age & $\leq 30$ days & $>30$ days \\
\hline \multirow{2}{*}{ Delayed referral } & $<7$ years & 41 & 5 \\
\hline & 7 years $\leq$ & 30 & 4 \\
\hline \multirow[t]{3}{*}{ Delayed diagnosis } & $<7$ years & 32 & 14 \\
\hline & 7 years $\leq$ & 28 & 6 \\
\hline & & $\leq 14$ days & $>14$ days \\
\hline \multirow[t]{2}{*}{ Delayed treatment } & $<7$ years & 40 & 6 \\
\hline & 7 years $\leq$ & 31 & 3 \\
\hline
\end{tabular}

the beginning of treatment. Most of them did not refer to witchcraft as a method for the treatment of cancer; in fact, they mentioned witchcraft as a complementary treatment of cancer. They acknowledged that cancer should be treated with medical and surgical procedures and this referral continued after the start of treatment, but it did not have any preventive power in the continuation of the treatment. 
Table 6. Relation between distance of residence and variety of delays

\begin{tabular}{lccc}
\hline Type of delay & Distance & $\mathbf{3 0}$ days & $>\mathbf{3 0}$ days \\
Delayed referral & Urban & 29 & 2 \\
& Rural & 42 & 7 \\
Delayed diagnosis & Urban & 27 & 4 \\
& Rural & 33 & $>\mathbf{1 4}$ days \\
\hline \multirow{3}{*}{ Delayed treatment } & & $\leq 14$ days & 1 \\
& Urban & 30 & 8 \\
\hline
\end{tabular}

Table 7. In comparison with kinds of all delays and factors influencing on delays

\begin{tabular}{|c|c|c|c|c|c|c|c|}
\hline & Age & Gender & $\begin{array}{l}\text { Mother } \\
\text { work }\end{array}$ & $\begin{array}{l}\text { Father } \\
\text { work }\end{array}$ & distance & $\begin{array}{l}\text { Mother } \\
\text { education }\end{array}$ & $\begin{array}{l}\text { Father } \\
\text { education }\end{array}$ \\
\hline Delay refer & .917 & 1.000 & 1.000 & .410 & .470 & $\begin{array}{c}\mathrm{R}=-.191 \\
.090\end{array}$ & $\begin{array}{c}\mathrm{R}=+.054 \\
.637\end{array}$ \\
\hline Delay diagnosis & .650 & .389 & .311 & .450 & .048 & $\begin{array}{c}R=-.094 \\
.408\end{array}$ & $\begin{array}{c}\mathrm{R}=+.060 \\
.596\end{array}$ \\
\hline Delay treatment & .337 & .250 & 1.000 & .097 & .143 & $\begin{array}{c}\mathrm{R}=+.043 \\
.707\end{array}$ & $\begin{array}{c}\mathrm{R}=+.006 \\
.955\end{array}$ \\
\hline
\end{tabular}

$\mathrm{p}<0.05$ is significant, $\mathrm{R}=$ Pearson's correlation that can range from -1 to 1

\section{Denial of reality}

It was revealed that there is no significant relationship between the normal process of psychological reactions to the acceptance of the disease and delay in the onset of treatment.

\section{Mistrust in the treatment}

From among the patients who had a delay in the beginning of the treatment, $33.3 \%$ of them referred to this factor as the reason for their delay; thus, a long time was spent on searching for other methods to treat the disease.

It should be mentioned that the parents were asked about the distance of the route, their psychological problems after being informed of the cancer diagnosis, high cost of treatment and the reaction of relatives as the possible reasons for delayed treatment. However, they did not mention any of these factors as the ones that might have led to the delay in their referral or in the beginning of treatment, but they found these factors a major cause of continued treatment.

\section{Decision to discontinue treatment}

In response to the question of whether or not the parents decided to discontinue treatment $25 \%$ of children stated that they had made such a decision at least once, $68 \%$ referred to despair of recovery and treatment-related side effects as the reasons, $23 \%$ referred to economic factors, and $9 \%$ referred to other factors, such as family problems and lack of family support as the causes of delay.

A comparison of the kinds of delays and factors influencing delays is illustrated in Table 7.

\section{DISCUSSION}

With the increase of human longevity and the change of environmental conditions, the improvement of cancer diagnostic methods has witnessed an increasing trend, especially in developing countries where there is a lower quality of environmental factors, food safety, health, and living conditions. However, advances in diagnostic methods have contributed to the identification of cancer patients and this along with the betterment of treatment methods has brought a higher degree of hope for the treatment and increased quality of life in these patients. Since the quick and timely diagnosis has a very important role in the treatment process of cancer, this study sought to evaluate the amounts of the aforementioned delays from the incidence of the first symptoms and to determine the causes of these three types of delays so that basic strategies would be presented with the aim of reducing patients' delay in referral, diagnosis, and treatment.

In the present study, no relationship was found between children's age and delay in referring to the physician; however, a similar study was carried out in Nigeria in 2015 
where the results represented the existence of a negative significant correlation between children's age and the delay in diagnosis. In another study which was conducted in South Africa in 2010 by Dr. Stefan's team, a delay in initial referral was found to hold no significant association with age, gender, and ethnicity $(9,10)$. Similar results with the current findings were also obtained in terms of gender that may lead to the conclusion that most parents did not discriminate between their children in this regard despite the culture of gender discrimination in most societies.

Few studies have been conducted on the role of parents' education and knowledge, especially on children; however, Dr. Stephen also reported similar results (9). In contrast, various studies have been conducted on the overall role of education in diagnosis and treatment at various age groups and the majority of these studies have lent support to the positive effect of education, training, and knowledge in this area $(8,11)$.

In relation to the difference between urban and rural areas in terms of the initial referral and onset of treatment, Bain and Campbell conducted a study in 2000 at Oxford University and reported that rural patients are less hopeful about treatment and they start their treatment later under the belief that they are faced with more obstacles in receiving intensive care (12). In the same way, a study was undertaken on 200 women with breast cancer at Tehran University in 2005 and residence in rural areas was referred to as the cause of delay in initial referral (13).

In comparison with the result of the present study which was carried out a decade later and due to the non-significance of distance from treatment centers as one of the causes of delay in referral, it can be argued that the expansion of health centers, establishment of family doctors even in the most remote rural areas, and a referral system have played an effectively positive role in this domain. In fact, these patients mentioned other factors, such as referral to multiple physicians after the final diagnosis, denial of reality, lack of confidence in the treatment method, and high costs of treatment as the reasons for their delays. According to the research findings and considering the culture of our country, spells and casting spells are not regarded as an acceptable treatment method for cancer. In fact, patients stated other applications for making spells and have acknowledged that cancer should be treated with medical and surgical methods. However, they emphasized the positive impact on their spirit and psyche of using spells $(14,15)$.

In a systematic study which was conducted in 2015, the following four factors were identified as the most important causes of delays in referral and seeking treatment: care-giving barriers, coordination of the health system with patients, the type of communication, the interactions of the care-giving system with patients, and patients' personal values and relationships (16).

\section{CONCLUSION}

In the population of the present study, such characteristics as age, gender, occupation, and rural residence did not cause any delay in referring to the physician, but other factors, including the assignment of no importance to the primary symptoms and/or the serious consideration of these symptoms, habitual delay in referring to the physician, low level of economic status, lack of family support for the patient, and family problems were found to be the main reasons for such delays.

\section{SUGGESTIONS}

According to the research results, the following suggestions are recommended:

1) Necessary training and education should be taken more seriously to familiarize the public, especially school students and university students, with the warning signs of cancer.

2) Patients and their families who have undergone mental problems after the diagnosis and try to deny reality should be helped immediately to improve this situation through psychoanalysis and social work services.

3) If the physician and the treatment system provide the patients and their relatives with necessary information and assurance regarding diagnostic methods and treatment procedures, patients can spend time on the treatment rather than on visiting several doctors.

4) The poor and low-income strata should be financially supported and their insurance situation should be improved.

5) Convincing the patients about the side effects of treatment will cause them not to think of stopping the continuity of treatment nor to think of treatment discontinuation immediately after relative recovery.

6) Early diagnosis of cancer is important for preventing the rising death rate from cancer. In order to improve this situation, it requires a timely visit to the physician, timely diagnosis of the disease, and the improvement of treatment methods.

Acknowledgment: The authors thank all the patients and their parents who participated in study. Also, many thanks to the Department of Molecular Medicine, Faculty of Advanced Medical Science of Tabriz University for their support.

Ethics Committee Approval: This study was approved by Ethics and Human Rights Committee of Tabriz University of Medical Sciences.

Informed Consent: Written consent was obtained from the participants.

Peer Review: Externally peer-reviewed. 
Author Contributions: Conception/Design of Study- S.M., A.H.P.; Data Acquisition- S.M., A.H.P.; Data Analysis/Interpretation- R.H., R.S.; Drafting Manuscript- R.H., R.S., S.M.; Critical Revision of Manuscript- S.M., A.H.P; Final Approval and Accountability- S.M., A.H.P., R.H., R.S.; Technical or Material Support- S.M.; Supervision- S.M., A.H.P.

Conflict of Interest: Authors declared no conflict of interest.

Financial Disclosure: Authors declared no financial support.

Teşekkür: Yazarlar çalışmaya katılan tüm hastalara ve ebeveynlerine teşekkür eder. Ayrıca, Tebriz Üniversitesi Illeri Tıp Bilimleri Fakültesi, Moleküler Tıp Bölümü'ne desteklerinden dolayı çok teşekkür ederiz.

Etik Komite Onayı: Bu çalışma için etik komite onayı Tebriz Tıp Bilimleri Üniversitesi Etik ve İnsan Hakları Komitesi'nden alınmıştır.

Bilgilendirilmiş Onam: Katılımcılardan bilgilendirilmiş onam alınmıştır.

Hakem Değerlendirmesi: Dış bağımsız.

Yazar Katkıları: Çalışma Konsepti/Tasarım- S.M., A.H.P.; Veri Toplama- S.M., A.H.P.; Veri Analizi/Yorumlama- R.H., R.S.; Yazı Taslağı- R.H., R.S., S.M.; İçeriğin Eleştirel İncelemesi- S.M., A.H.P.; Son Onay ve Sorumluluk- S.M., A.H.P., R.H., R.S.; Malzeme ve Teknik Destek- S.M.; Süpervizyon- S.M., A.H.P.

Çıkar Çatışması: Yazarlar çıkar çatışması beyan etmemişlerdir.

Finansal Destek: Yazarlar finansal destek beyan etmemişlerdir.

\section{REFERENCES}

1. Siegel RL, Miller KD, Jemal A. Cancer statistics, 2016. CA Cancer J Clin 2016;66:7-30. [CrossRef]

2. Manohar PR, editor. Descriptions and Classification of Cancer in the Classical Ayurvedic Texts. Indian Nat Sci Acad; 2015. [CrossRef]

3. DeSantis $C E$, Lin $C C$, Mariotto $A B$, Siegel RL, Stein $K D$, Kramer JL, et al. Cancer treatment and survivorship statistics, 2014. CA Cancer J Clin 2014;64:252-71. [CrossRef]

4. Girgis A, Lambert S, Johnson C, Waller A, Currow D. Physical, psychosocial, relationship, and economic burden of caring for people with cancer: a review. J Oncol Pract 2012;9:197-202. [CrossRef]
5. Chan CMH, Ahmad W, Azman W, MD Yusof M, Ho GF, Krupat E. Effects of depression and anxiety on mortality in a mixed cancer group: a longitudinal approach using standardised diagnostic interviews. Psychooncology 2015;24:718-25. [CrossRef]

6. Berry DA, Cronin KA, Plevritis SK, Fryback DG, Clarke L, Zelen $\mathrm{M}$, et al. Effect of screening and adjuvant therapy on mortality from breast cancer. N Engl J Med 2005;353:178492. [CrossRef]

7. Walter F, Webster A, Scott S, Emery J. The Andersen Model of Total Patient Delay: a systematic review of its application in cancer diagnosis. J Health Serv Res Policy 2012;17:110-8. [CrossRef]

8. Ermiah E, Abdalla F, Buhmeida A, Larbesh E, Pyrhönen S, Collan Y. Diagnosis delay in Libyan female breast cancer. BMC Res Notes 2012;5:452. [CrossRef]

9. Stefan DC, Siemonsma F. Delay and causes of delay in the diagnosis of childhood cancer in Africa. Pediatr Blood Cancer 2011;56:80-5. [CrossRef]

10. Brown BJ, Adeleye AO, Ibeh JN. A prospective study on the causes of delayed diagnosis of childhood cancer in Ibadan, Nigeria. Pediatr Hematol Oncol 2015;32:365-73. [CrossRef]

11. Murata C, Yamada T, Chen C-C, Ojima T, Hirai H, Kondo K. Barriers to health care among the elderly in Japan. Int J Environ Res Public Health 2010;7:1330-41. [CrossRef]

12. Farmer J, Iversen L, Campbell NC, Guest C, Chesson R, Deans $G$, et al. Rural/urban differences in accounts of patients' initial decisions to consult primary care. Health Place 2006;12:210-21. [CrossRef]

13. Harirchi I, Ghaemmaghami F, Karbakhsh M, Moghimi R, Mazaherie $H$. Patient delay in women presenting with advanced breast cancer: an Iranian study. Public Health 2005;119:885-91. [CrossRef]

14. Meraviglia MG. Prayer in people with cancer. Cancer Nurs 2002;25:326-31. [CrossRef]

15. Rezaei M, Adib-Hajbaghery M, Seyedfatemi N, Hoseini F. Prayer in Iranian cancer patients undergoing chemotherapy. Complement Ther Clin Pract 2008;14:90-7. [CrossRef]

16. Sampson R, Cooper J, Barbour R, Polson R, Wilson P. Patients' perspectives on the medical primary-secondary care interface: systematic review and synthesis of qualitative research. BMJ Open 2015;5:e008708. [CrossRef] 